\title{
PENGARUH MODEL PEMBELAJARAN PROBLEM BASED LEARNING (PBL) TERHADAP SIKAP PEDULI LINGKUNGAN DAN HASIL BELAJAR IPA SISWA KELAS IV SDN 78 KOTA BENGKULU
}

\author{
Deliza Septika Triani ${ }^{1}$, Endang Widi Winarni ${ }^{2}$, Abdul Muktadir ${ }^{3}$ \\ Fakultas Ilmu Pendidikan dan Keguruan Universitas Bengkulu \\ Email: delizayahya@gmail.com
}

\begin{abstract}
ABSTRAK
Penelitian ini bertujuan untuk mengetahui pengaruh model pembelajaran PBL terhadap sikap peduli lingkungan dan hasil belajar IPA siswa kelas IV SDN 78 Kota Bengkulu. Jenis penelitian ini kuantitatif dengan metode penelitian Quasi Eksperimental Design. Sampel penelitian adalah SDN 78 Kota Bengkulu. Instrumen penelitian ini berupa angket sikap peduli lingkungan dan tes hasil belajar. Data hasil penelitian ini dianalisis menggunakan analisis inferensial yaitu uji-t. Hasil penelitian sikap peduli lingkungan siswa ini menunjukkan hasil Uji-t dengan $t_{\text {hitung }}$ 0,70 dan nilai $t$ hitung hasil belajar IPA siswa 3,83. Adapun nilai $\mathrm{t}$ tabel dengan taraf signifikan $\alpha=5 \%$ pada sampel sebesar 2,00. Karena pada kedua variabel sikap peduli lingkungan dan hasil belajar IPA $t$ hitung $>t$ tabel, maka dapat disumpulkan bahwa terdapat pengaruh penerapan model pembelajaran PBL terhadap sikap peduli lingkungan dan hasil belajar IPA siswa kelas IV SDN 78 Kota Bengkulu.
\end{abstract}

Kata Kunci : Model Pembelajaran PBL, Sikap Peduli Lingkungan, Hasil Belajar IPA

\begin{abstract}
This study aims to determine the effect of PBL learning model on environmental care attitudes and science learning outcomes of fourth grade students of SDN 78 Kota Bengkulu. This type of research is quantitative with the Quasi Experimental Design research method. The study sample was SDN 78 Kota Bengkulu. The instrument of this research is in the form of environmental care questionnaire and learning outcomes test. Data from the results of this study were analyzed using inferential analysis, namely the t-test. The results of the research on the students 'environmental care attitude showed the results of the t-test with $t$ count of 0.70 and the value of students' $t$ science learning outcomes calculated at 3.83. The value of $t$ table with a significant level of $\alpha=5 \%$ in the sample of 2.00. Because on both the environmental care and science learning outcomes $t$ count $>t$ table, it can be concluded that there is an effect of applying the PBL learning model to the environmental care attitude and science learning outcomes of fourth grade students of SDN 78 Kota Bengkulu.
\end{abstract}

Keywords: PBL Learning Model, Environmental Care Attitude, Science Learning Outcomes 


\section{PENDAHULUAN}

Pendidikan menurut UU SISDIKNAS No. 20 tahun 2003 adalah usaha sadar dan terencana untuk mewujudkan suasana belajar dan proses pembelajaran agar peserta didik secara aktif mengembangkan potensi dirinya untuk memiliki kekuatan spiritual keagamaan, pengendalian diri, kepribadian, kecerdasan, akhlak mulia, serta keterampilan yang diperlukan dirinya dan masyarakat.1 Tujuan pendidikan nasional adalah mencerdaskan kehidupan bangsa dan mengembangkan manusia Indonesia seutuhnya, yaitu manusia yang beriman dan bertaqwa terhadap Tuhan Yang Maha Esa dan berbudi pekerti luhur, memiliki pengetahuan dan keterampilan, kesehatan jasmani dan rohani, kepribadian yang mantap dan mandiri serta rasa tanggung jawab kemasyarakatan dan kebangsaan. Permasalahan mutu pendidikan seringkali dikaitkan dengan merosotnya prestasi belajar yang dicapai siswa. Banyak faktor yang menyebabkan rendahnya pencapaian hasil belajar diantaranya yang cukup dikenal adalah sifat ilmu itu, pelaksanaan pembelajaran yg kurang baik, dan karakter pembelajarannya.

Pendidikan adalah sarana yang tepat untuk meningkatkan dan mengembangkan kualitas Sumber Daya
Manusia (SDM). Dalam rangka mewujudkan SDM yang unggul dan berdaya saing maka pendidikan harus didesain sedemikian rupa guna mempersiapkan generasi yang kompeten. Salah satu bentuk upaya yang dapat dilakukan adalah dengan meningkatkan mutu pendidikan.

IPA merupakan ilmu yang berkaitan dengan cara mencari tahu tentang alam secara sistematis, sehingga IPA bukan hanya penguasaan kumpulan pengetahuan yang berupa fakta-fakta, konsep-konsep, atau prinsip-prinsip saja tetapi juga merupakan suatu proses penemuan (Permendiknas No. 22 tahun 2006). Menurut Trianto (2007) Ilmu Pengetahuan Alam (IPA) merupakan pengetahuan ilmiah, yaitu pengetahuan yang telah mengalami uji kebenaran melalui metode ilmiah, dengan ciri objektif, metodik, sistematis, universal, dan tentatif. Ilmu Pengetahuan Alam merupakan ilmu yang pokok bahasannya adalah alam dan segala isinya. Lingkungan merupakan salah satu unsur dari alam. Kondisi lingkungan global dewasa ini semakin memprihatinkan. Hal ini disebabkan oleh ulah manusia yang mengekploitasi sumber daya alam dan lingkungan tanpa batas. Berkaitan dengan perilaku manusia terhadap kondisi sumber 
daya alam dan lingkungan yang cenderung tidak peduli, maka perlu ditekankan pendidikan karakter peduli lingkungan. Penanaman nilai-nilai kepedulian terhadap lingkungan dapat dilakukan melalui pendidikan. Salah satu implementasi penanaman sikap peduli lingkungan dapat diintegrasikan dalam kurikulum pada mata pelajaran IPA. Pembelajaran IPA mengajarkan siswa untuk memelihara dan menghargai alam.

Akan tetapi masalah lingkungan yang semakin tak terkendali menunjukkan bahwa pendidikan lingkungan hidup belum berhasil membentuk sikap manusia yang peduli terhadap lingkungan hidup seperti: 1) masih rendahnya pertisipasi masyarakat untuk berperan dalam lingkungan hidup, karena kurangnya pemahaman terhadap permasalahan pendidikan lingkungan, rendahnya tingkat kemampuan atau keterampilan dan rendahnya komitmen pada masyarakat dalam menyelesaikan permasalahan tersebut. 2) pemahaman pelaku pendidikan terhadap pendidikan lingkungan yang masih terbatas. Dalam jalur pendidikan formal, masih ada anggapan bahwa pendidikan lingkungan hidup tidak begitu penting. 3) materi dan metode pelaksanaan pendidikan lingkungan hidup dirasakan belum memadai dan kurang aplikatif, sehinggapemahaman kelompok sasaran mengenai pelestarian lingkungan hidup menjadi tidak utuh. 4) srana dan prasarana dalam pendidikan lingkungan hidup belum mendapat perhatian yang cuku. Sarana dan prasarana lingkungan hidup sering kali disalah artikan sebagai sarana fisik yang berteknologi tinggi sehingga menjadi faktor penghambat tumbuhnya motivasi dalam pelaksanaan pendidikan lingkungan hidup. 5) lemahnya koordinasi antar instansi terkait dan para pelaku pendidikan menyebabkan kurang berkembangnya pendidikan lingkungan hidup. (Desfandi, 2015: 32-33).

Rendahnya hasil belajar IPA antara lain disebabkan: 1) pembelajaran masih bersifat interaksi satu arah; 2) dalam pembelajaran, model pembelajaran yang digunakan kurang bervariasi; 3) pembelajaran IPA dijadikan pembelajaran yang bersifat hapalan; 4) siswa belum terlibat aktif dalam pembelajaran; 5) masih adanya siswa yang belum mencapai KKM 68.

Pentingnnya menjaga lingkungan belum selurunya tertanam pada manusia seperti halnnya pada siswa di SD Negeri 78 Kota Bengkulu. Berdasarkan hasil observasi awal, diketahui bahwa masih banyak siswa yang membuang sampah sembarangan, beberapa dari mereka bahkan membiarkan sampah yang tergeletak tidak pada tempatnya. Hal ini tentunya disebabkan oleh kurangnnya 
sikap peduli lingkungan yang ada pada dalam diri siswa.

SD Negri 78 Kota Bengkulu juga telah mengadakan piket kelas yang dilakukan setiap harinya, kegiatan tersebut dimaksudkan untuk menumbuhkan dan membiasakan sikap peduli lingkungan kepada siswa, akan tetapi dari kegiatan itu belum cukup karena kegiatan kebersihan tersebut belum dilakukan secara optimal dan masih banyak siswa yang kurang peduli menjaga lingkungan sekolah agar tetap indah dan bersih.

Kurangannya sikap peduli lingkungkungan siswa salah satunya disebebkan oleh kurangnnya pendidikan lingkungan yang diperoleh siswa. Pendidikan lingkungan yang diberikan berupa kebersihan yang dilakukan diluar jam pelajaran, guru kurang menyisipkan pendidikan lingkungan kedalam proses pembelajaran sehingga sikap peduli lingkungan dalam proses pembelajaran kurang tertanam pada diri siswa.

Untuk menjadikan pembelajaran IPA menjadi pembelajaran yang bermakna dan menyenangkan, banyak sekali model pembelajaran yang dapat digunakan dalam melatih siswa berpikir kritis. Salah satu model pembelajaran yang dapat diterapkan dalam memperbaiki sikap peduli lingkungan dan hasil belajar siswa dengan menerapkan model Problem Based Learning (PBL).
Adapun menurut Widiasworo (2017:171) Problem Based Learning merupakan suatu model pembelajaran yang menantang peserta didik untuk belajar bagaimana belajar, bekerja secara kelompok untuk mencari solusi dari permasalahan dunia nyata.

Berdasarkan data yang diperoleh dari penelitian terdahulu yaitu Ipmawati, (2017:262) menyatakan bahwa penerapan dengan menggunakan pendekatan Problem Based Learning sangat baik diterapkan dimata pelajaran Ilmu Pengetahuan Alam, karena siswa dapat aktif untuk berpikir dan berkonstruktif. Susanti, (2017) terdapat perbedaan sikap peduli lingkungan antara siswa yang diajarkan menggunakan model pembelajaran problem based learning dengan siswa yang di ajar menggunakan metode konvensional. Bilqis (2015:137) menyatakan bahwa terdapat perbedaan hasil belajar kognitif siswa yang menggunakan model problem based learning dengan yang menggunakan model pembelajaran langsung. Serta hasil belajar kognitif siswa yang menggunakan model problem based learning lebih tinggi daripada siswa yang menggunakan model pembelajaran langsung.

Berdasarkan permasalahan diatas dapat disimpulkan bahwa proses pembelajaran IPA yang menjadi salah satu cara untuk menumbuhkan sikap. permasalahan tersebut harus diatasi salah 
satu yang dapat dilakukan dalam memperbaiki sikap peduli lingkungan dan hasil belajar IPA dalam kelas dengan menerapkan model pembelajaran. Pembelajaran IPA yang dilaksanakan harus menggunakan model pembelajaran yang banyak melibatkan partisipasi siswa secara langsung model yang digunakan adalah Problem Based Learning ( PBL)

Tujuan dari penelitian ini adalah : 1) Untuk mengetahui pengaruh model pembelajaran PBL terhadap sikap peduli lingkungan siswa kelas IV SD Negeri 78 Kota Bengkulu. 2) Untuk mengetahui pengaruh model pembelajaran PBL terhadap hasil belajar siswa kelas IV SD Negeri 78 Kota Bengkulu.

\section{METODE PENELITIAN}

Penelitian ini dilaksanakan di SD Negeri 78 Kota Bengkulu yang berlokasi di jalan Raya Betungan Kota Bengkulu pada kelas IV semester genap Tahun Pelajaran 2017/2018. Penelitian ini dilakukan mulai bulan Mei sampai bulan Juni 2018.

Populasi dalam penelitian ini adalah seluruh kelas IV SD Negeri 78 Kota Bengkulu. Total populasi sebanyak 56 siswa. Sampel dalam penelitian ini berjumlah 56 siswa. Kelas IVA berjumlah 30 siswa sebagai kelompok eksperimen, dan kelas IVB dengan jumlah 26 siswa sebagai kelompok kontrol.
Setelah ditemukan permasalahan seperti di atas, populasi dan sampel telah ditetapkan. Maka, langkah selanjutnya adalah menyusun instrumen tes angket sikap peduli lingkungan dan tes hasil belajar. Instrumen divalidasi oleh pakar ( ekspert judges). Hasil validasi yang telah dilanjutkan oleh pakar, dapat dilanjutkan dengan uji coba instrumen. Pada penelitian ini data yang dikumpulkan adalah sebagai berikut. 1) data sikap peduli lingkungan siswa diperoleh dengan cara memberikan angket. 2) data hasil belajar IPA diperoleh dengan melaksanakan hasil belajar IPA dalam bentuk tes objektif pilihan ganda dengan empat pilihan.

Teknik analisis data yang digunakan adalah kuantitatif. Data yang diperoleh akan dianalisis menggunakan dua jalur dan uji perbedaan dua rata-rata (uji-t), yang bertujuan untuk melihat apakah ada perbedaan antara sikap peduli lingkungan dan hasil belajar dengan menerapkan model PBL. Pengolahandan analisis data yang dilakukan menjadi pembakuan instrumen penelitian, uji prasyarat, analisis deskriptif, dan pengajuan hipotesis.

\section{HASIL DAN PEMBAHASAN}

\section{Hasil Penelitian}

Berdasarkan hasil uji hipotesis penelitian menyimpulkan bahwa: 1) Ada pengaruh model pembelajaran PBL terhadap sikap peduli lingkungan siswa 
antara kelas yang menggunakan PBL dengan kelas yang menggunakan pembelajaran konvensional dalam pembelajaran IPA pada siswa kelas IV SDN 78 Kota Bengkulu, terlihat dari nilai rata-rata kelas yang menggunakan $\mathrm{PBL}$ dari 37 menjadi 81 atau meningkat sebesar 44 sedangkan pada kelas konvensional yaitu dari 36 menjadi 77 atau meningkat sebesar 41. 2) Ada pengaruh model pembelajaran PBL terhadap hasil belajar siswa antara kelas yang menggunakan PBL dengan kelas yang menggunakan pembelajaran konvensional dalam pembelajaran IPA siswa kelas IV SDN 78 Kota Bengkulu, terlihat dari rata-rata kelas yang menggunakan PBL dari 63,07 menjadi 76,27 atau meningkat sebesar 13, 2 sedangkan pada kelas konvensional yaitu dari 62,46 menjadi 66.00 atau meningkat sebesar 3,54.

\section{Pembahasan}

\section{Pengaruh Model Pembelajaran}

\section{PBL terhadap Sikap Peduli Lingkungan}

Siswa

Berdasarkan hasil analisis data angket yang diperoleh dari penelitian ini, terlihat peningkatan perilaku peduli siswa terhadap lingkungan yang signifikan pada siswa kelas eksperimen. Siswa kelas IVA sebagai kelas eksperimen menunjukkan perubahan perilaku kepedulian terhadap lingkungan setelah peneliti menerapkan model pembelajaran PBL dalam materi saat penelitin. Peneliti memanfaatkan lingkungan siswa sebagai alternatif masalah yang harus mereka temukan dan pecahkan dalam kegiatan pembelajaran. Dengan penerapan tersebut, terlihat peningkatan yang sangat signifikan dari pertemuan pertama dan kedua serta ditemukan perbedaan yang cukup tinggi antara angket kelas kontrol dan eksperimen.

Penelitain yang dilakukan oleh Djuandi (2016) menemukan data bahwa siswa yang megalami perlakuan PBL dalam kegiatan pembelajaran memiliki sikap kepedulian terhadap lingkungan yang tinggi daripada siswa yang tidak memperoleh perlakuan PBL. Badarudin (2018) juga menguatkan dengan pernyataan bahwa terdapat peningkatan terhadap sikap peduli lingkungan siswa yang mendapat perlakuan kegiatan pembelajaran PBL . Penyataan serupa dinyatakan oleh Sumiyanto (2016) bahwa kelas yang memperloleh perlakuan PBL mampu nenunjukkan sikap kepedulian terhadap lingkungan serta kemampuan berfikir kritis yang lebih baik dibandingkan dengan kelas yang tidak memperoleh perlakuan.

Berdasarkan hasil penelitian diatas, dapat disimpulkan bahwa penerapan model pembelajaran PBL juga berpengaruh dalam sikap kepedulian siswa terhadap lingkungan. Hal ini mendukung 
pernyataan dari Mardiana (2016) bahwa salah satu model pembelajaran yang direkomendasikan oleh kurikulum 2013 yang efektif dalam memicu kepekaan sikap siswa terhadap lingkungan. Menurut Widiasworo (2017:172), bahwa proses belajar pada PBL tidak hanya menera fakta dan informasi semata, namun belajar merupakan suatu proses interaksi antara peserta didik dengan lingkungan.

\section{Pengaruh Model Pembelajaran}

\section{PBL terhadap Hasil Belajar IPA Siswa}

Berdasarkan uji hipotesis yang telah dilakukan dapat diketahui bahwa dengan pembahasan materi yang sama pada siswa kelas IVA lebih unggul dibandingkan dengan siswa kelas IVB. Diketahui siswa kelas IVA merupakan kelas eksperimen yang diberikan tindakan berupa proses pembelajaran dengan menerapkan model pembelajaran PBL, sedangkan kelas IVB hanya menerapkan model pembelajaran berkelompok. Hal serupa dilakukan oleh Syafriana (2017), dalam penelitiannya juga menujukkan peningkatan hasil belajar IPA yang dilihat dari pengamatan prasiklus, siklus I dan siklus II. Selanjutnya penelitain yang dilakuakan oleh San, (2016) menyatakan bahwa model pembelajaran PBL memiliki pengaruh dalam meningkatkan hasil belajar siswa. Novialiswati (2018) menemukan data bahwa PBL mampu meminimalisir siswa yang nilainya berada dibawah KKM yang semula 7 orang menjadi 1 orang setelah diberikan perlakuan kegiatan pembelajaran dengan menerapkan model pembelajaran PBL pada siswa.

Hasil analisis $\mathrm{t}$ tes menunjukkan bahwa terdapat perubahan yang sangat signifikan antara pre test dan post test siswa kelas eksperimen setelah menerapkan model pembelajaran PBL. Hal ini sejalan dengan penelitian yang dilakukan oleh Bilqis (2016), bahwa hasil belajar kognitif siswa meningkat lebih tinggi setelah menerapkan model pembelajaran PBL pada kelas eksperimen. Widiasworo (2017:171), mengatakan bahwa model pembelajaran PBL merupakan model pembelajaran yang menyajikan masalah kontekstual sehingga merangsang peserta didik untuk belajar. Artinya dengan melibatkan kontekstual dalam proses pembelajaran, daya logikal siswa lebih terbuka sehingga merangsang berkembangnya kognitif siswa dalam memahami dan memaknai materi yang dipelajari dengan menghubungkan dengan lingkungan mereka sendiri. Dengan demikian, siswa lebih tetarik serta aktif dalam mengikuti setaiap aktifitas dalam kegiatan pembelajaran. Hal ini menjadi salah satu pemicu meningkatnya kemampuan kognitif atau hasil belajar siswa. Penelitain yang dilakukan oleh Ayunengsih (2017) menemukan 
pernyataan bahwa PBL berpengaruh terhadap pestasi belajar siswa. Artinya efektifitas PBL terhadap penigkatan kemampuan kognitif siswa tidak dapat diragukan lagi.

Tujuan PBL seperti yang disampaikan oleh Hosnan (2014:298) bahwa target PBL adalah agar siswa memperoleh berbagai pengalaman dan mengubah tingkh laku siswa. Dilanjutkan oleh Widiasworo (2017:172) bahwa belajar dengan pengalaman akan melibatkan proses pengembangan mental secara lebih utuh, mulai dari kognitif, afektif dan psikomotor. Artinya hasil penelitian pada kelas eksperimen dengan menerapkan model pembelajaran PBL sangat efektif bilamana target guru adalah menigkatkan hasil belajar siswa. Pembelajaran IPA pada ruang lingkup Sekolah Dasar meliputi hal-hal yang berhubungan dengan diri dan lingkungan siswa. setiap gejala pada diri mereka dan lingkungan siswa akan sangat efektif jika dijadikan alternatif permasalahan yang dimunculkan dalam menerapkan proses pembelajaran di kelas pada siswa.
Berdasarkan hasil analisis data, dapat disimpulkan bahwa :

1. Terdapat pengaruh penerapan model pembelajaran PBL terhadap sikap peduli lingkungan siswa kelas IV SDN 78 Kota Bengkulu. Analisis data hasil penelitian menunjukkan bahwa nilai $\mathrm{t}_{\text {hitung }} 2,70$ dan $\mathrm{t}_{\text {tabel }} 2,00$. Artinya $t_{\text {hitung }}>t_{\text {tabel }}$ sehingga Ha diterima.

2. Terhadap pengaruh penerapan model pembelajaran PBL terhadap hasil belajar IPA siswa dikelas IV SDN 78 Kota Bengkulu. Analisis data hasil penelitian menunjukkan bahwa nilai $\mathrm{t}$ hitung 3,83 dan $t_{\text {tabel }} 2,00$. Artinya $t_{\text {hitung }}>$ $\mathrm{t}$ tabel sehingga Ha diterima.

\section{SIMPULAN}


Ayunengsih, D, dkk. 2017. Pengaruh Model Problem based learning dan kematangan terhadap prestasi prestasi belajar siswa. Bengkulu : Teknologi Pendidikan

Badarudin. 2018. Peningkatan Sikap peduli lingkungan dan prestasi belajar IPA menggunakan model Problem based learning berbasis literasi pada subtema lingkungan tempat tinggalku dikelas IV MI Muhammadiyah keramat. Purwokerto : Pendidikan Dasar Indonesia

Djuandi, D. 2016. Pengaruh Pembelajaran berbasis masalah terhadap sikap siswa pada lingkungan. Subang : Jurnal Pendidikan Geografi.

Hazami, dkk. 2015. Pengembangan perangkat pembelajaran berorientasi pendidikan sikap peduli lingkungan dengan metode Hypotecing pada materi pencemaran. Semarang : Jurnal pendidikan IPA

Indriwati, A, Dkk. 2016. Pembelajaran Berbasis masalah dengan bahan ajar berorientasi sumber daya peraiaran terhadap karakter peduli lingkungan dan hasil belajar IPA. Semarang : FMIPA UNNES
Novialistwati, T, dkk. 2018. Penerapan Model Problem based learning (PBL) untuk meningkatkan hasil belajar pada subtema pelestarian sumber daya alam indonesia. Subang : Didaktik

Prihatini, E, dkk. 2017. Pengaruh model Problem based learning dan PJBL terhadap hasil belajar Biologi Pada Materi Pencemaran Lingkungan Siswa SMA N 2 Kota Tebing Tinggi. Medan : Prodi S2 Biologi USU

San, S. 2016. Pengaruh Model Pembelajaran Problem based learning dan motivasi belajar terhadap hasil belajar sains siswa SD. NTT : STKIP Citra Bakti Ngada.

Syafriana, D. 2017. Penerapan model Problem based learning (PBL) dalam peningkatan saintifict untuk meningkatakan hasil belajar IPA kelas V SDN 63 Surabaya. Jakarta: Prodi Pendas UNJ

Winarni, W. E. 2016. Pengaruh Pelaksanaan Program Pengurangan Resiko Bencana Terintegrasi Menggunakan Model Problem based learning Berbasis ICT bagi siswa kelas IV SDIT IQRA' Di Kota Bengkulu. Bengkulu : FKIP UNIB 